\title{
Flying on the wings of Vollenhoven's radical Christian worldview: A reconsideration of the usual typology of Christian worldviews
}

Author:

Barend J. van der Walt ${ }^{1}$

Affiliation

${ }^{1}$ School of Philosophy, North-West University, Potchefstroom Campus, South Africa

Correspondence to:

Barend van der Walt

Email:

benniejvanderwalt@gmail. com

Postal address:

7 Bezuidenhout Street, Oewersig, Potchefstroom

2531, South Africa

Dates:

Received: 05 July 2011

Accepted: 07 Nov. 2011

Published: 22 Oct. 2012

How to cite this article: Van der Walt, B.J., 2012,

'Flying on the wings of Vollenhoven's radical Christian worldview: A reconsideration of the usual typology of Christian worldviews', Koers - Bulletin for Christian Scholarship 77(1), Art. \#31, 14 pages. http://dx.doi.org/10.4102/ koers.v77i1.31

\section{Note:}

This article was developed from a paper delivered at the Koers-75 Conference on 'Worldview and Education', held in Potchefstroom, South Africa, from 30 May to 02 June 2011.

Hierdie artikel is ' $n$ verdere ontwikkeling van ' $n$ voordrag gelewer by die Koers-75 Konferensie oor 'Worldview and Education' in Potchefstroom, Suid-Afrika, vanaf 30 Mei tot 02 Junie 2011

(C) 2012. The Authors. Licensee: AOSIS OpenJournals. This work is licensed under the Creative Commons Attribution License.
This article investigated the traditional typology of Christian worldviews from the perspective of the Christian philosopher, D.H.Th. Vollenhoven (1892-1978). The usual categorisation started by Niebuhr (in 1951), and adopted by some Reformational scholars afterwards, is questioned as too simplistic, forcing Christian thinkers and schools of thought into five pigeonholes. Worldviews - including the Christian ones - are complex phenomena. They should not be considered, for example, as merely logical systems or aesthetic 'stories'. Vollenhoven's systematic philosophy and historiography of philosophy (his thetical-critical approach) can provide some clues for a new way to describe different Christian worldviews, as well as to arrive at the outlines of a more radical and comprehensive Christian worldview based on God's threefold creational, inscripturated and incarnated revelation.

Om te vlieg op die vlerke van Vollenhoven se radikale Christelike lewensvisie: 'n Herevaluering van 'n gangbare tipologie van Christelike lewensvisies. Hierdie artikel ondersoek in hoofsaak die tradisionele tipologie van Christelike lewensvisies vanuit die perspektief van die Christelike filosoof, D.H.Th. Vollenhoven (1892-1978). Daarvolgens word die gangbare kategorisering, wat by Niebuhr (in 1951) 'n aanvang neem en later ook deur verskeie reformatoriese denkers aanvaar is, bevraagteken as te simplisisties, omdat dit Christelike denkers en denkskole in slegs vyf tipes probeer indeel. Die artikel toon aan dat lewensvisies - ook die Christelikes - meer komplekse verskynsels is. Hulle mag byvoorbeeld nie as blote logiese of estetiese 'stories' beskou word nie. Vollenhoven se sistematiese filosofie en sy filosofiese historiografie (sy teties-kritiese benadering) bied belangrike suggesties vir ' $n$ nuwe wyse om verskillende Christelike lewensbeskouings te bestudeer en bied daarbenewens ook die moontlikheid om 'n duideliker, radikaler en omvattender Christelike lewensvisie, wat op God se drievoudige skeppings-, skrif- en vleesgeworde openbaring gegrond is, te vergestalt.

\section{Prescript}

\section{Tendele Camp, KwaZulu-Natal, early morning, 01 January 2011}

I am taking a long walk to Tiger Falls. It is nearly the end of our holiday in our beloved Drakensberg Mountains and I am already thinking ahead of all that has to be done in the coming year of our Lord 2011. Included in all of them is also an article on worldview for the Koers-75 Conference. What kind of thing is a worldview? Is it a logical system or, as people say today, a story? Why does one need a worldview? For what purpose?

Next to the footpath dewdrops sparkle like small pearls on the grass blades. From far below I can hear the sound of the river. When I look further around small waterfalls are tumbling from the mountains. In the chinchi bushes next to the path the cicadas start their amazing noise. Ants are hurriedly crossing my path, carrying pieces of grass to their nests. A dung-beetle is struggling to roll away what an eland has left to him. When I sit down in the shadow of a huge cabbage tree, the calling of different birds reaches my ears. And when I looked up again, two grey reedbucks are grazing peacefully between the shrubs not far away, unaware of my presence.

What a morning! The whole creation, from the inanimate dewdrops, to the plants, insects, birds and mammals, each in its own unique way are praising their Creator. I joined in with my own doxology:

When through the woods and forest glades I wander,

I hear the birds sing sweetly in the trees,

When I look down from lofty mountain grandeur 
And hear the brook and feel the gentle breeze; Then sings my soul, my Saviour God, to thee: How great thou art, how great thou art!

Then sings my soul, my Saviour God to thee:

How great thou art, how great thou art!

Why should a worldview only be a way of looking and thinking about the world? Why should it be regarded merely as an interesting story? Why can it not also be viewed as a song - a song of praise and honour to our Creator? Is this not both the essence and purpose of a real Christian worldview? But how can one acquire such a Christian worldview? What should it look like?

I was now searching the clear blue sky with my binoculars. Yes, there they are! Two lammergeyers are floating on the currents of the wind a few thousand metres above. Amazing birds, these black-bearded eagles! They can fly fast, far and high. And with incredible eyesight they can spot small details far below.

Eureka! I have it! Apart from a doxology, a genuine Christian worldview should also enable one to fly high and with sharp eyes to look far and wide and deep below.

\section{Introduction}

\section{Commemorating two milestones}

This introduction intends briefly to draw attention to the past, enabling us to understand the background of two important occasions that occurred during 2011.

In 2010, Koers, a journal for Christian scholarship (published in Potchefstroom, South Africa) was in its seventy-fifth year of publication (under its preceding names, even longer). Not many scholarly journals survive three quarters of a century! In the same year, the Association for Christian (previously Reformational) Philosophy (ACP) (in the Netherlands) could also look back on a lifetime of 75 years. Not many Christian organisations last so long! Therefore it was a privilege to participate, in 2011, in these joyous commemorations and by way of small contributions also express my own gratitude to God for what he has given us in both of them. For the sake of context, I mention only something briefly about the long and rich tradition both Koers and the ACP represent: their impact, different personalities, viewpoints and contexts.

\section{A worldwide impact}

Both Koers and the ACP were established with the idea to promote a Christian worldview, Christian philosophy and a Christian approach to other scholarly disciplines. Their existence for so long has proven that such an idea was not a freak or a fad that could impress people only for a few years. It has gained a legitimate existence over the last 75 years (next to other philosophical currents and worldview traditions), providing biblically inspired, normative direction.

In the second place, this movement for Reformational thinking is no longer limited to Potchefstroom or Amsterdam.
It is acknowledged today in different parts of the world (cf. Van der Walt 2010a:127-151). It binds together Christian scholars in different disciplines around the globe. It is also perhaps too slowly - beginning to drop its Western garb to be contextualised in other cultures such as those of Africa, the Far East and South America.

\section{Different personalities}

At such commemorations one looks back for a moment to remember not merely a journal and an organisation, but also the human beings who wrote for and published in Koers and who kept the ACP going through all these years. In Potchefstroom, some of them were my own teachers (Christian theologians and philosophers), such as Professors H.G. Stoker, J.A.L. Taljaard and P.G.W. du Plessis - to mention only the philosophers. Apart from their different philosophies, each one of them was a fascinating personality. The same applies to the Netherlands. Klapwijk (1987) has written an interesting book in which he portrayed the unique personalities of people such as D.H.Th. Vollenhoven, H. Dooyeweerd and others. They were not birds of the same feather!

\section{Different viewpoints}

Critical outsiders sometimes think that Christian philosophers or academics in general form a clique, singing the same song. Or that present-day Christian philosophers are simply following 'the master's voice' of, for example, Stoker or Dooyeweerd. This, however, is not true. They are not only differently 'feathered', but - like birds - they also in the past 'sang' and today still 'sing' different philosophical songs.

Already the fathers (Dooyeweerd, Stoker \& Vollenhoven) did not agree on everything (cf. Tol 2011). During the second generation (in the Netherlands) Mekkes, Popma, Van Riessen and Zuidema each had their own emphasis and made their unique contributions. The same applies to the next generation. To mention only four examples: Goudzwaard's emphasis mainly was on ideologies and their influence on socioeconomic-political life (cf. Goudzwaard 1984; Goudzwaard, Vander Vennen \& Van Heermst 2007), Klapwijk (1995) proposed his own transformational philosophy, Schuurman (1995) worked on the implications of a Christian worldview and philosophy for contemporary technology, whilst Bril and Tol (cf. Vollenhoven 1992) kept the heritage of Vollenhoven alive and relevant.

\section{Different contexts}

All the thinkers in this rich and varied tradition (for more details cf. again Van der Walt 2010a:127-151) were not only influenced by their own times. They also challenged their contemporary cultural and philosophical context and its problems. For example, Vollenhoven had to fight against the stagnant Reformed theological Scholasticism or Orthodoxy of his day (cf. Tol 2010). Zuidema (1971) especially wrote in confrontation with existentialist and pragmatist irrationalist philosophies. Klapwijk (1970) again faced the relativism of historicism. Smit (1987) struggled with complex problems in 
the philosophy of history. Indeed, what I want to emphasise is that each of them did not philosophise in the vacuum of an ivory tower. Every one of them tried to give Christian philosophical and worldviewish direction amidst the confusion of the dominant worldviewish and philosophical tendencies of their times.

The same was to happen again at the International Koers-75 Conference, as well as the International Symposium in Amsterdam. The Koers-75 Conference aimed at providing worldviewish guidance in education, whilst the Symposium (held in August 2011), with its central theme 'The future of the creation order', was to do the same on a philosophical level amidst rampant normative directionlessness. I was especially excited about the Koers Conference, experiencing something similar to the many conferences organised by the Institute for Reformational Studies (IRS) (closed in 1999). May the legacy of the IRS be continued in new ways!

\section{The relevance of a worldview approach in the context of present-day Christianity}

Many beautiful African fables ascribe human characteristics to different animals and birds. I am not an avid bird-watcher, but allow me to typify contemporary Christianity with a few of our African bird species - especially to emphasise some of their attitudes toward our increasing secular environment.

\section{Some current Christian attitudes towards their secular context}

I do not think it is necessary to provide bibliographical proof for the following attitudes amongst some Christians. With open eyes and ears one will be able to recognise at least some of them:

- The innocent doves resemble many faithful Christian churchgoers who seem narrowly to identify being a Christian with only attending church on Sundays and are unaware of a suffering, dangerous and secular world surrounding them.

- The noisy hadeda ibis makes us think about those Christians who proclaim loudly that 'Christ is the answer!', but they do not tell us to which current problem(s) he provides an answer.

- The secretive night owl is blinded by the bright light of present-day scientific-technological-commercial culture. They know intuitively that everything that glitters is not necessarily good. But lacking normative guidance of a real biblical worldview, they do not know how to discern critically between good and bad in contemporary culture.

- Rehearsing parrots can be divided in two groups of Christians. The one simply repeats what it picks up from its secular environment. The other Christian group is of the opinion that to solve every problem a Christian should simply repeat, in a biblicist way, what is written in the Bible. They do not realise that they often read their own preconceived ideas into Scriptures. And they do not acknowledge that God also revealed himself in his creation and in his final incarnated revelation, Jesus Christ.

- The isolationist woodpecker prefers to lay its eggs in the deep hole of a tree trunk where it feed its chickens. Likewise, some Christians today 'emigrate' from the 'world' to the 'safety' of a cosy family and church life, unconcerned about the world outside.

- The sociable weavers may look different from the woodpeckers, but actually they confine themselves to their own species. In the same way, some Christians today regard their ethnic loyalty, religious affiliation or political party as more important than their Christian faith. (Christians in South Africa, for instance, are today still divided because of their political alliances, whilst they should together get involved in politics from a Christian worldview perspective).

- In the case of another species of weavers, during mating time the male changes the colour of his feathers into a brilliant yellow or red to attract the females. In a similar way, some Christians simply change their 'colour' according to circumstances and would even be involved in unchristian behaviour such as corruption, fraud, immorality, et cetera.

- The lazy red-crested cuckoo thinks that she can lay her eggs, have them hatched and fed by another kind of bird, without her offspring experiencing any identity or normative crisis when they grow up. Likewise, some Christian parents think they can send their children to secular schools without any damage.

- The violent, anti-thetical secretary bird is our next example. With its strong legs it kicks a snake (the secular devil) to pieces, only - ironically - to swallow it afterwards because of the lack of the alternative: a solid Christian worldview.

- The ingenious hammerkop builds its large and strong nest in the fork of a tree (up to $50 \mathrm{~kg}$ and so strong that its roof can withstand the weight of a full grown man) from nearly any material available - sticks, reeds, weeds and all kinds of debris, including human-made artefacts. In the same way, many Christians today construct eclectically their own personal worldview in a postmodern manner from all kinds of bits and pieces derived from books, the media, friends, et cetera.

At the end of this metaphorical description of the confusion amongst Christians today about their place and task in the world, the question may be asked whether a worldview approach can help us out of the uncertainty.

\section{A worldview approach as solution also for Christians}

Where does the concept of a worldview comes from and why should Christians use it?

\section{Not an original Christian invention}

A worldview idea was not an original discovery of Christian thinkers (cf. Bonzo \& Stevens 2009; Naugle 2002; Wolters 1989:15-16), but was derived from the German word 'Weltanschauung'. By the 1840s it had become a standard item in the German philosophical vocabulary, indicating a global 
outlook on life and the world, similar to philosophy but without its rational pretensions and therefore regarded as a relative historic-culturally determined phenomenon.

\section{The Christian faith as a worldview}

Christian scholars took over this idea to explain that also their Christian faith entails a worldview. Colson and Pearcey (1999) write:

\begin{abstract}
Genuine Christianity is more than a relationship with Jesus, as expressed in personal piety, church attendance, Bible study and works of charity. It is more than discipleship, more than believing a system of doctrines about God. Genuine Christianity is a way of seeing and comprehending all reality. It is a worldview ... The way we see the world can change the world. (pp. 14, 15)
\end{abstract}

Looking back on the question 'What does it mean to be a Christian?', we can see that different answers have been given through the past 2000 years. For example, (1) a Christian is someone who believes or understands correctly (orthodoxy), (2) a Christian should do something or live correctly (orthopraxis) and (3) a Christian should feel good or experience something. For this latest tendency, the article by Ramaker (2007) offers worthwhile reading. (Behind all these views lies the ageold unbiblical anthropological debate about the priority of reason, will and emotion.)

Today, however, we have come to realise that Christianity entails much more. If conversion does not include also a change at the worldview level, then the Gospel becomes the captive of a local culture and is interpreted in terms of an unbiblical worldview. To this end, Hiebert (2008) writes:

Conversion must encompass ... worldview. Christians should live differently because they are Christians. However, if their behavior is based primarily on traditional rather than Christian beliefs, it becomes pagan ritual. Conversion must involve a transformation of beliefs, but if it is a change only of beliefs and not behavior, it is false (James 2). Conversion must include a change in beliefs and behavior, but if the worldview is not transformed, in the long run the gospel is subverted and the result is Christo-paganism which is the form of Christianity but not its essence... If behavioral change was the focus of the mission movement in the nineteenth century, and changed beliefs its focus in the twentieth century, then transforming worldviews must be its central task in the twenty-first century. (p. 11)

Previously, Runner (1982) provided us with the following clear distinctions between conversion, revival and reformation:

A conversion is the work of the Holy Spirit in the heart of a person so that he submits himself to the claims of Christ, our Savior and Lord. A revival is the renewal of faith of a number of persons within a particular part of the church at a particular time in history. A reformation is a revival so radical and wide-spread that it affects the direction of the culture and the structuration of society. (Runner 1982:cover page)

However, according to Runner (1982), the impact of the many conversions and revivals in the history of Christianity were confined mostly to the private lives of Christians and the churches. There was no spillover to the larger context of culture and society. The main reason for this absence of real reformation was that the revivalists did not preach the Word of God in such a way that its redeeming power was brought to bear on the entire life of the people of God. A truly biblical worldview could help to overcome this weakness.

\section{Contextualisation requires a Christian worldview}

Also, Wolters (2005:142) emphasises that a biblically based worldview fulfils a necessary mediating role in a Christian's calling. Appropriate contextualisation requires the conceptualisation of such a worldview (cf. also Bartholomew \& Goheen 2010.) Recently, Griffioen (2012) summarised the value of a worldview approach in the following words:

The genius of the worldview notion is that it signifies both an inner conviction and an outlook on the world. Thus it combines the personal and the universal. Moreover, it does so in the context of conflicting convictions and outlooks. (p. 19)

One can understand why, since Abraham Kuyper (who transformed Calvinism from an initially theological system into a worldview at the end of the 19th century), numerous books have been written on a Christian or Reformational worldview and its application to various areas of life. (The bibliography at the end could only refer to a few of them.) It became a hit, I think, because a worldview enables one to make your faith relevant and practical for all aspects of life (cf. Van der Walt 2008). Faith is no longer confined to one's personal devotions or church life. (Because many definitions exist of what a worldview exactly is, I am not going to try a new one - most readers of Koers will know what I have in mind.)

\section{Focus on Vollenhoven (1892-1978)}

In this article, I want to put the spotlight on only one of the many Christian philosophers of the past 75 years, one of the fathers of this movement.

Firstly, it is necessary to include something on a personal note to explain my appreciation for Vollenhoven's ideas. As a young student, Prof. J.A.L. Taljaard introduced me to Vollenhoven's systematic philosophy and historiography (cf. Vollenhoven n.d.[a], n.d.[b]). Then, I had the privilege (still as a student) to attend a series of 24 lectures Vollenhoven presented (during the second semester of 1963) as a guest lecturer at the then Potchefstroom University for Christian Higher Education, now the North-West University these lectures were only published nearly 50 years later in Vollenhoven (2011). In 1968, I wrote my Master's thesis on Thomas Aquinas according to Vollenhoven's consequential problem-historical method. During my studies at the Vrije Universiteit of Amsterdam (1968-1970), I also followed the privatissima [private classes], which the retired and mature Vollenhoven gave to interested students. Afterwards (1975), also in my DPhil thesis, I used Vollenhoven's historiography of philosophy to analyse Thomas, Calvin and the Synopsis Purioris Theologiae (of 1625).

\section{Vollenhoven: The African fish eagle of Reformational philosophers}

Following the behaviour of the different birds (discussed earlier), I want to compare Vollenhoven to an African fish 
eagle (Haliaeetus vocifer). I use it as metaphor because it can fly higher, see sharper and wider than other birds and announces its presence with a distinctive voice.

The reader may detect that I am an admirer of - not an expert on - Vollenhovian thinking. He may be the greatest Christian thinker yet. As a Christian philosopher (not a Christian doing philosophy) he has, in my mind, surpassed Calvin. (I can claim this because Calvin wrote a Christian worldview in his famous Institutes, but he did not develop a Christian philosophy.) Vollenhoven was a giant, but deep in his heart he remained an ordinary child of God with a sincere faith and unsophisticated humility. He gave his heart to God and his Word, and never put his final trust in philosophy - not even his own. Philosophy was, to him, only a fallible aspiration towards wisdom. It should not deceive people by proclaiming a final truth. The word of God alone can answer our deepest questions and longings.

Many philosophers today act, as Socrates recommended, only as gadflies. Others can be compared to blind moles, digging around in dark, underground tunnels. But Prof. Dirk Vollenhoven, to me, is the eagle amongst the philosophers. He flew high - on the wings of God's threefold revelation (in creation, the Bible and Christ) and the winds of the Holy Spirit. He looked widely around him - his worldview. He did so with very sharp philosophical eyes - carefully detecting similarities, differences and relationships. His worldviewish and philosophical voice was distinct - undoubtedly Christian. But, like any eagle, he did not keep flying high above our heads, but also returned to earth - his philosophy and worldview is also of eminent practical value.

\section{Vollenhoven neglected}

In spite of this, Vollenhoven's work was, for many years, only known and appreciated by a small group of Christian scholars. Many reasons for this sad state of affairs may exist. Perhaps the most important factor was that, compared to Dooyeweerd, very little of Vollenhoven's oeuvre was, until recently, available in the lingua franca of today. (Dooyweerd's major work, A new critique of theoretical thought, had been published already in the 1950s.)

\section{New wings to Vollenhoven's philosophy}

From the centenary commemoration of Vollenhoven's birth in 1992, however, new publications of him and about him started emerging. In Dutch, some of his publications were edited by Tol and Bril (cf. Vollenhoven 1992), whilst Kok (1992) wrote a dissertation on Vollenhoven's early thought, and Stellingwerff (1992) wrote a biography (in Dutch) on this reformer of philosophy. Kok (1998) was also responsible for a popularised version of Vollenhoven's survey of the history of Western Philosophy.

Since 2000, more momentum has been achieved. On Vollenhoven's consequential problem-historic method of historiography Bril and Boonstra (cf. Vollenhoven 2000) edited and explained his Schematic maps. Subsequently, Bril edited a Dutch, as well as an English, version of Vollenhoven's historiographical method and history of philosophy (cf. Vollenhoven 2005a, 2005b), as well as his many contributions on philosophy in the Oosthoeks Encyclopedie (cf. Vollenhoven 2005c). A simplified version of Vollenhoven's historiography is provided by Van der Walt (2010b:152-182).

Simultaneously, Vollenhoven's own systematic philosophy also got new wings through the following publications. Kok and Tol (cf. Vollenhoven 2005d) edited his Isagôgè Philosophiae [Introduction to Philosophy] in both Dutch and English. Most recently, Tol (cf. Vollenhoven 2010) was responsible for a text-critical edition of the same work. Finally, Tol (2010) also wrote an excellent dissertation on Vollenhoven's own philosophical development from 1918 to 1931 (for a summary, see Tol 2011).

\section{Vollenhoven's style}

Even to a Vollenhoven expert such as Tol, Vollenhoven's philosophy is not an easy cup of tea - especially for a novice. He (cf. Tol 2010:60) says 'Vollenhoven's thought is for many not an easy nut to crack'. And he calls Vollenhoven's Isagôgè a challenge: 'Vollenhoven guides without taking away the initiative from the student. The student and the reader need to think, and to think hard when following Vollenhoven' (Tol 2010:41).

Much of the difficulty is the result of Vollenhoven's brief and succinct style:

\begin{abstract}
$\ldots$ brevity and succinctness don't always serve for clarity when there is need for explanation ... On reading Vollenhoven, one soon realizes that his brevity of expression cloaks a complex process of thought ... Vollenhoven's succinctness evidences a talent for combining beguiling simplicity with deep subtlety, sweeping generalization with careful distinction. Here Vollenhoven is at his best. He has an impressive grasp of details, but always with a view to the framework in which they fit. (Tol 2010:26)
\end{abstract}

\section{The focus on Vollenhoven's worldview}

Because of the difficulties to walk with Vollenhoven's scholarly philosophy, this article is an attempt to fly with his pre-scientific, more basic worldview. I am of the opinion that Reformational philosophy could have a greater impact if beginners start on a worldviewish level.

\section{Religion, worldview and philosophy}

Already in his dissertation, Vollenhoven (1918) was convinced that being a thinker and a Christian can be combined. This conviction remained unchanged throughout his career. According to Vollenhoven, his Christian philosophy is the correlate, in science, of a Christian view of the world, which is non-scientific in character. Philosophy and worldview are therefore related but not the same; philosophy is the scientific elaboration of a worldview. Limited space does not permit a detailed discussion of the relationship between the two (cf. e.g. Wolters 1989:24). Because of this close relationship, one 
may deduce the worldviewish background from his Isagôgè Philosophiae, his main systematic work, as well as from his historiography of philosophy.

Both worldview and scholarship (philosophy included), in turn, are built on a still deeper level, viz. that of religion and can therefore never be neutral activities. Tol (2010:255) therefore distinguishes firstly the religious level, secondly the worldviewish level and thirdly the level of thought, summarising Vollenhoven's viewpoint as follows:

philosophy is 'fed' by worldview (life-experience) and religious attitude (life-fulfilment), but ... philosophy 'digests' these in terms of its own limited possibilities. Philosophy's food is meta-philosophical, but what it stomachs is philosophical. (Tol 2010:256)

\section{Encompassing religion}

In the light of the Scriptures, Vollenhoven (2005d:78) describes religion as follows: '... the relationship of humankind to the God of the covenant in obedience or disobedience to his fundamental law of love'. In this definition, God's Word clearly reverberates (cf. e.g. Gn 15; Ex 19:5; Dt 33:9; Ps 25:10; 103:18; 132:12; Is 56:4, 6; Dn 9:4).

Because Vollenhoven simultaneously sees a close religious relationship, as well as a clear ontological distinction, between God, his creation and his laws for creation, religion is not something spiritual, supernatural, ethereal or merely ecclesiastical - a separate part of human life. In an encompassing way, with our whole existence, here and now - in the most simple earthly things and activities - we have, according to his commandments, to walk coram Deo, close to God. Life in its entirety - worldview and education included - should be religion!

\section{To fly with Vollenhoven's worldview}

We will return to Vollenhoven's own ideas in more detail, but I now invite the reader to fly with me - like an African eagle - on the wings of Vollenhoven's worldview. Unfortunately because of a lack of space - we will have to confine ourselves mainly to (1) Vollenhoven's possible corrections on the current categorisation or typology of Christian worldviews, (2) his own alternative, (3) possible limitations of his own approach and (4) a brief application of his worldview to education in general.

\section{Vollenhoven's possible corrections on some Christian worldviewish publications}

Vollenhoven may be critical about different methods of describing and categorising Christian worldviews.

\section{Methods are not neutral}

A method presupposes amongst others, (1) an aim (e.g. a survey of or insight into a specific problem), (2) careful planning to enable one to reach the goal, (3) execution of the plan by a person or an apparatus controlled by the researcher, (4) with due consideration of the material that has to be studied and (5) the means at one's disposal (cf. Stoker 1969).

A real method therefore will not simply be collecting 'facts' to put them in line next to one another. Method implies precision and planning, but also that one intends to get somewhere, to let the facts 'talk', both separately and as a whole. A method could either let the data (information) say something or suppress it. But even more importantly: every method is - whether one is conscious of it or not determined by deeper presuppositions. No method (both scientific and pre-scientific) can be neutral, because it is based on epistemological, anthropological, ontological and religious assumptions.

Vollenhoven required his own method(s) to be at least conceived in the light of God's Word (Ps 36:10) and that it should be truly philosophical. He did not agree, for instance, that geographical, chronological, nationalistic (ethnic), etc., methods could really study the history of philosophy correctly. (We will return to Vollenhoven's own method below.) This contribution limits Vollenhoven's critique to the following three issues to be discussed separately below. Firstly, a worldview is not (as the word itself suggests) a relative view about only the world. Secondly, 'creation fall redemption' cannot fully express the contents of a biblically based worldview. Thirdly, Christian worldviews should not be categorised according to a nature-grace distinction.

\section{A worldview is not something merely cultural or only a view about the world}

In Vollenhoven's time, the term 'worldview' was, for nonChristian thinkers, primarily a term to indicate mainly cultural attitudes (cf. my argument above in this regard). It therefore also implied relativism: so many cultures, so many worldviews.

Vollenhoven would not accept this. As indicated already above, religion to him is the basis of both worldview and philosophy. Every worldview is religiously determined. Therefore the word 'worldview' (with the emphasis on world) itself may be queried because it gives the impression that God, his commandments and the religious relation of humankind to him is excluded. A believing Christian, however, cannot understand the world outside its relationship to God and his ordinances.

According to Vollenhoven, any philosophy worth its salt has to ask two basic questions, (1) 'What is or exist?' and (2) 'How should it be?' The first is a structural or ontic question; the second a directional or religious one. The answer to the first reveals different more or less constant types of worldviews and philosophies. The answer to the second focuses on different normative, spiritual currents in the history of worldviews and philosophies. These spiritual streams do not stay the same but change with time. Types and currents also have a mutual influence on each other. 
What is fundamental to Vollenhoven's thinking therefore is the distinction as well as the close relationship between structure (creation) and its (religious) direction. And after the fall into sin two directions should be distinguished: good and bad or obedience and disobedience to God's law. The law provides a normative - directional element to a worldview. Hence, we can summarise Vollenhoven's worldview as follows: it does not only include the world, but also God and his laws. The human being is called by God to an office to fulfil a task in creation according to his laws.

\section{'Creation, fall and redemption' do not clearly enough express a Christian worldview}

To my mind, Vollenhoven, for the following reasons, will not regard as satisfactory the summary of a Christian worldview as 'creation, fall and redemption', as proposed by Dooyeweerd (1959, 1979), Stoker (1967:13-41, 42-82, 1970:430) and many Reformational thinkers afterwards, such as Bartholomew and Goheen (2010), Walsh and Middleton (1984:41-90), Wolters (2005) and Zijlstra, in Runner (1982:23-33).

Firstly, in line with what was said already above, I argue that it is because the theme of creation, fall and redemption deals primarily with the history of creation and only implicitly with God and his norms. Vollenhoven describes this kind of thinking as 'purely cosmological' - it focuses narrowly only on this world. A student of Vollenhoven, Taljaard (1976), elaborates on Vollenhoven's critique of reducing biblical revelation to merely the 'creation, fall and redemption' of the cosmos. According to Taljaard (1976:86), this idea already started with the Roman Catholic thinker, Thomas Aquinas, and can also be traced in the philosophies of Dooyeweerd and Stoker (cf. Taljaard 1976:46, 85). Such a view has serious implications, such as the fact that only theology has to do with God and his revelation, whilst (Christian) philosophical study is confined to the cosmos and therefore secularised. God's sovereignty over his entire creation can therefore not be proclaimed in a Christian worldview. Taljaard (1976:29) regards such implications as so detrimental that he would rather reject the word 'worldview', to be replaced by a prescientific view of the realities of God, the cosmos and his laws for created reality.

Secondly, Vollenhoven, who strongly emphasises the genesis or continued development of the world after its creation, would like to add a fourth element: its final consummation. Thirdly, I do not think Vollenhoven would have liked the idea that redemption only implies a return to the original, perfect pre-fall situation. This was the viewpoint of Bavinck (cf. Veenhof 1994), viz. grace restores nature, and perhaps also Wolters (2005) in his book Creation regained.

Fourthly, creation, fall and redemption tends to take into consideration only God's revelation in the Bible and not his revelation in creation. Given the threefold facets of God's revelation (i.e. creational, scriptural and incarnational), emphasising only one of them (e.g. the scriptural revelation of the Bible), or devaluating any one form of his revelation undermines the two other forms. To minimise or ignore any part of God's complete revelation sooner or later also distorts one's relationship to God as well as one's role in the world. Biblicism, which wants to derive all guidance from the Bible only, easily results in a dualistic worldview of nature and supernature. (Vice versa: such a dualism is the source of Biblicism.) This leads onto a third possible query from Vollenhoven below.

\section{Categorising Christian worldviews according to the model of nature-grace is unsatisfactory}

Some brief notes about Bavinck, Niebuhr, a few Reformational thinkers, and Carter and Ramaker are important to understand Vollenhoven's possible critique. All of them apply only four or five 'boxes' to categorise different worldviews.

\section{Herman Bavinck}

Bavinck categorised different Christian worldviews according to the scholastic dualism of nature and grace. According to Bavinck, the Anabaptist's position was grace against nature, whilst the Catholics elevated grace above nature, the Lutherans positioned grace next to nature and the Calvinist view was that grace restores nature.

Veenhof (1980:66) indicates that Bavinck struggled throughout his career with the problem of the relationship between creation and recreation, general and special revelation, nature and grace. Bavinck criticised other Christian worldviews (cf. Veenhof 1968:345-365, 1994), but could never really solve the problem. His own viewpoint (expressed in Bavinck 1888, 1904a, 1904b, 1908 and other publications) was that grace does not abolish nature, but purifies, renews, heals and restores it. Heideman (1959:196) writes: '. . that grace does not abolish nature, but renews and restores it ... may be called the central thought of Bavinck's theology.'

I agree with Bavinck that God's salvation is intended for creation. But what exactly defines their relationship is difficult to tell if one views it from a basic nature-grace starting point. I also do not see a radical difference between the viewpoint of Bavinck and that of Thomism, which he criticised. (According to Vollenhoven 2000:51 and others, Bavinck's philosophical position was the same as that of scholastics such as Thomas Aquinas, Suarez and Jungius.)

\section{H. Richard Niebuhr}

Niebuhr (1951) followed a similar line: Christ (or grace) against culture (nature), Christ above culture, Christ and culture in paradox, Christ transforms culture (his own preference) and Christ of culture. He was criticised afterwards for forcing all Christian thinking into only five boxes or pigeonholes.

\section{Reformational thinkers}

We find more or less the same later on with Reformational philosophers (cf. Olthuis 1970:105-125; Wolters 1990:189-203; 
Zijlstra, in Runner 1982:24-34 and, to a lesser extent, Walsh \& Middleton 1984). Wolters also discovers five categories of Christian worldviews in history: grace opposes nature, grace perfects nature, grace flanks nature, grace restores nature and grace equals nature. I have also adopted the same scheme in the past (cf. e.g. Van der Walt 2001:26).

\section{Craig A. Carter}

Recently, Carter (2006) proposed to rethink this classic categorising of Niebuhr and his followers. His main argument is that the scheme was devised from the presupposition of a Christian world (corpus Christianum), which today no longer exists in the West. From his own background (historically Anabaptist and strongly influenced by the contemporary writings of Yoder) he argues for a separation between Christ and culture, which, according to him, can still be culturally creative. However, I get the impression that such a perspective finally boils down to salvation from creation rather than the salvation of creation. (I leave unanswered the question of whether one's secular environment can become so devilish that perhaps the only remaining option for Christians may be to withdraw.)

\section{Timon Ramaker}

Most recently, Ramaker (2007:150-156) also critically reviewed Niebuhr's division of Christian worldviews into five categories. Firstly, he - correctly - discerns a dualism in the 'Christ and culture' approach. Secondly, he regards the idea of Christians being able to transform the contemporary dominating and powerful secular culture as too optimistic, belonging to a triumphalistic phase in the history of Christianity. Christians should rather approach present-day culture (of which they are part) in a critical-participatory way, in other words, both accepting and correcting it. They should, as salt and light, be followers of Christ.

\section{The nature-grace method as the 'vitium originis'}

The most important question we have to ask is about the method which lies behind this traditional typology of Christian worldviews (see my argument above). What are the philosophical presuppositions (both structural and directional) supporting such a method? Is the method, for instance, devised in the light of God's (scriptural) revelation?

The main problem with all of the above attempts to categorise worldviews is that they are based on the age-old dualism between nature (or culture) and grace (in Christ). The only difference between the (five) types of Christian worldviews is that they view the relationship between nature and grace differently. It may be in order if one accepts the distinction 'nature-grace' as biblical. Unfortunately, it is not the case. It has to be rejected in the light of God's revelation (cf. Walsh \& Middleton 1984:41-90, as well as Vollenhoven in many of his publications).

What is even worse is that the nature-grace dualism historically prepared the way for contemporary secularism, when nature (the world) was divorced from grace to become autonomous and a completely secular domain. According to Vollenhoven (2005a:65), the distinction between nature and grace was a method applied by Christian synthetic thinkers to combine pagan thinking (the lower sphere of nature) and God's revelation (the higher sphere of supernature or grace). The result was synthesis thinking - which caused unimaginable harm to the Christian faith and robbed religion of its biblical, all-encompassing nature. Viewed from the one side, synthetic thought resulted in the nature-grace method, whilst viewed from the other side, the nature-grace method facilitated synthetic thinking.

However, according to Vollenhoven, God created everything, Christ indicates the direction of life (according to his command of love) in all aspects of life, the Spirit motivates, guides and calls to responsibility in everything we do. Every human being is created, addressed and guided. From his side every human being (as prophet, priest and king) has a fulltime religious office to fulfil. Life - one's entire life - is religion!

\section{A brief critique}

The nature-grace theme is basically a confusion between the structure of the world ('nature') and its (religious) direction ('grace'). The spiritual antithesis (between obedience or disobedience to God's law) is given ontological status by defining some sectors, parts, aspects, realms or activities (such as the church) as, by nature, good and others (e.g. politics) as less good and even evil. Some callings (for example that of ministers) are regarded as higher and holier than others, whilst celibacy is seen as being purer than marriage, evangelism more saintly than social involvement and theology more honourable than philosophy. Therefore some sectors of life are religious, whilst others (the 'natural' domain) are religiously neutral; some activities or structures are redeemable, others only remotely so (cf. Spykman 1992:67). Indeed, Spykman (1992) concludes about this kind of dualism:

... [it] is a deceptive attempt to reject life in the world (in part) while at the same time also accepting it (in part) ... [it] disrupts the unity of creation order ... legitimatize the reality of sin in one or other realm of life ... limit the cosmic impact of the Biblical message of redemption ... confine Christian witness to only certain limited sectors of life. (p. 68)

\section{Conclusion}

In light of the above, the conclusion can only be that to categorise Christian worldviews according to the method of nature-grace (supernature) is biblically unacceptable. The proposed Reformational or transformational view of grace transforming nature seems to be basically not very different from the classical Catholic position (cf. Wentsel 1970) of grace perfecting nature (gratia non tollit sed perfecit naturam).

Wolters, in spite of his critique (cf. 2005:79-92) on two realm theories (of nature-supernature), still seems to accept two regimes (2005:81). I can agree with him if he understands 'creation regained' in the sense that, according to the Bible, salvation (grace) does not stand outside creation (against, 
above or next to it), but is meant to renew creation itself. But if, from a sinful, fallen situation, one wants to regain creation (work backwards from a post-fall to a pre-fall situation), how can you be sure to have a real grasp on the structure and the laws governing the cosmos? (One is confronted here with the difficult problem of the noetic implications of the fall.)

It also seems to me the title of Wolter's book (now with the emphasis on 'creation regained') also implies a regressive element when he, for instance, writes (2005:83, emphasis mine): 'Redemption then is a recovery of creational goodness ... We return to creation through the cross ...' Yet, it may be that I misunderstand Wolters, for perhaps he meant 'regained' in another sense. Nonetheless, it remains an important issue to be investigated, bearing in mind the worldwide influence of Wolter's otherwise excellent book.

Recreation (paradise regained) cannot simply be a replacement of the original paradise lost. Neither can it be a restoration. In both cases, God's omnipotence becomes a problem. In the first case, it seems as if he was not powerful enough to redeem the first creation and could only replace it - Satan has won the battle! In the second instance, it looks as if God was not capable of preventing the fall and it is taking him millennia to regain it. The idea of a regained creation may, thirdly, imply a circular view of history, which goes against the biblical idea of a linear development towards fulfilment. Perhaps the best we may say is that future redemption is not simply a return to creation but nevertheless in line with creation, viz. simultaneously discontinuity and continuity.

\section{Vollenhoven's alternative}

The preceding critique on the traditional categorisation of Christian worldviews will become much clearer when we now turn to the detail of Vollenhoven's own viewpoint, including, (1) his method, (2) his division of history into three main periods and (3) its implications for a new typology of worldviews.

\section{Vollenhoven's own method}

It has already become clear that the question about which (philosophical) methodology one follows is of vital importance, because one's deeper religious, worldviewish and philosophical starting points are, in fact, built into your method (cf. my argument above). Vollenhoven was fully aware of this and paid elaborate attention to the correct philosophical method at the beginning of his Isagôgè (see Tol 2010 for the details). In the preceding part of this article, some glimpses of his method were already revealed. Because of its importance within the main argument of this article, a closer look is necessary. Vollenhoven (2005d:6-8) calls his own method the thetical-critical approach.

\section{A thetical method}

'Thetical' implies that one cannot think from a vacuum or tabula rasa, but that it is necessary to have a (preliminary) viewpoint. Therefore, Vollenhoven's own philosophy started with an answer to three basic questions (cf. Vollenhoven 2005d:14), (1) 'Who is the Creator?', (2) 'What is it that is created in relation to him?' and (3) 'Where does the line and bridge between them lie?' The Bible's answers to these are, (1) God, (2) his creation, completely dependent on its Creator and subjected to his sovereign law and (3) God's laws, the boundary and bridge between God and the cosmos. This distinction of God-law-cosmos became the hallmark of Vollenhoven's systematic philosophy and worldview.

\section{A critical method}

As an explanation of this, let me quote from Vollenhoven (2005d) himself:

We who philosophize may not act as though our predecessors and contemporaries lacked philosophic insight. On the contrary, we must seriously consider their expositions. However, we also may not swear by the words of a human master or seek a solution in a patchwork, in which simply out of awe for people of authority we borrow something from each of them. We must always ask ourselves: 'Did they sufficiently appreciate the difficulties and did they pose the problem correctly?' And we must also, and repeatedly, ask the same question of the result that we ourselves have arrived at. (p. 6)

Vollenhoven is clearly not against an open dialogue, whether positive or negative, with other viewpoints and worldviews. Vollenhoven also emphasises that criticism is not necessarily equivalent to negation. It can have a positive result of maintaining the position of another or oneself. Even a negative result has great value in obtaining new results.

\section{A thetical-critical method}

The thetical and critical elements are not isolated from each other, but should take place simultaneously. 'The theticalcritical brings systematic reflection and historical alternatives in direct contact with each other' (Tol 2010:31). In the words of Vollenhoven (2005d) himself:

Every critical activity implies that one takes a thetical position. It is quite possible that this position will later prove to be untenable, but all that it means is that one has modified one's position somewhat ... But whatever the case may be, all criticism presupposes, if it is worthy of the name, that one is confident in maintaining certain thoughts. (p. 7)

In an important following comment, Vollenhoven then rejects the following methods, (1) philosophic nihilism, (2) a simple combination of viewpoints and (3) eclecticism, which simply supports a number of ideas encountered, without even bothering whether they are compatible. (Compare again my avian metaphors of different kind of birds at the beginning of this article.) Vollenhoven (2005d) then summarises:

It is by maintaining that which is tenable in one's own position, by critically examining not only the result acquired by others but also the result of one's own thinking at an earlier time, and by having the courage to accept the implications of one's position, that one can make progress through struggle and attain a double profit: a reinforced position and a more definite rejection of whatever is inconsistent with it. (p. 8) 
Vollenhoven remained faithful to this method throughout his life: he described his own thetical position (cf. Vollenhoven 2005d) and, by way of his problem-historical method of historiography, he was critically involved with the ideas of others throughout history (cf. Vollenhoven 2000, 2005a, 2005b, 2005c). According to philosophical historiography, he distinguishes about 60 different normative currents or spiritual directions in the history of Western thinking as well as many types of philosophy about the structure of reality (cf. my argument above and Van der Walt [2010b] for an elementary introduction.) His own systematic philosophy (founded on God's Word) enabled him to delve wide and deep into the history of philosophy, whilst the insights he gained from the history of Western philosophy, in turn, enriched his own philosophy.

\section{Not anti-thetical but anti-synthetic}

Vollenhoven, therefore, was not simply an anti-thetic Christian philosopher. (An attitude still present in Kuyper.) On this point, even other Reformational thinkers may have misunderstood Vollenhoven (cf. Tol 2010:61, fn.). He did not put his own viewpoint anti-thetically - as the only correct one - over against non-Christian perspectives, regarding all of them as wrong. Vollenhoven thought anti-synthetically; he was against any kind of synthesis of biblical and unbiblical ideas. And his anti-synthetic thinking was not of a secular nature (ignoring God's revelation), but Christian (obeying God's revelation).

\section{Three methods employed in Christian synthetic thinking}

Vollenhoven's own method is totally different from the three methods employed in Christian synthetical thinking. The first that enabled Christians to combine unbiblical and biblical perspectives was the method of nature and grace (cf. my argument above). Pagan philosophy was regarded as a preamble to the supernatural sphere of God's revelation in the Bible.

Apart from nature and grace as a method of synthesis, Vollenhoven (2005a:62-63) also mentions the method of eisegesis-exegesis or biblicism, according to which unbiblical ideas are read into (eisegesis) the Word of God and read out (exegesis) again - now biblically sanctioned.

Thirdly, Vollenhoven (2005a:65) mentions the method of paradox. Tertullian, for example, accepted both pagan (Greek) conceptions and the Bible as authoritative. He realised that these two were at odds at more than one point, but he did not want to abandon either of them. So he arrived at a paradox, viz. that both the one and the other are true. Obviously an untenable viewpoint, but at least somewhat clearer than the two other methods in the sense that an unbiblical, pagan philosophy or worldview could not just be introduced into Scripture and in this way then be sanctioned by God's Word.

\section{Three main periods in the history of Western worldviews}

Vollenhoven then (cf. again Vollenhoven 2005a:29) takes synthetic thought (achieved by the above three methods to achieve a synthesis between biblically grounded ideas and unbiblical ones) as a dividing point in Western thinking:

- The pre-synthetic period (Greek, Hellenistic and Roman thought) stretched from the beginning of Western thinking (about $2500 \mathrm{BC}$ ) to approximately $50 \mathrm{AD}$.

- The synthetic period dominated the centuries from $50 \mathrm{AD}$ to about 1550 AD.

- The post-synthetic period was the time after 1550.

In the post-synthetic period, two different currents are distinguished: anti-synthetic right (or Christian) and left (or secular). Both of them have in common the fact that they reject a synthesis between biblical and unbiblical ideas. Their reasons for doing so, however, differed. The Christian movement (originating in the 16th century Reformation) rejected synthetic thinking because it wanted to get rid of the pagan element it contained. The secular trend (starting with the Renaissance) did so from an opposite motivation: it disliked the biblical element of synthetic thinking and (as least initially) wanted to return to Greek and Roman philosophy as guides to a new era in history.

Also, in this respect, Vollenhoven is not outdated today. On the one hand, secular thinking and worldviews are overwhelming us today. On the other hand, many Christians think that they can overcome secularism by returning to the synthetic thinking of the past (cf. the new Radical Orthodoxy movement). Or in a biblicistic way (as of old), they simply read into the Bible contemporary secular ideas and sanction them with sola Scriptura (a strong tendency amongst Reformed theologians today). Synthetic Christianity is also dominant on the African continent. Bediako (1992) identified similarities between early, Patristic synthetic thinking and contemporary African theologians. And Van der Walt (2011) draws attention to the dualistic worldview amongst Evangelicals in Africa.

\section{An important clarification}

Before we turn to the implications of the above (a new typology of worldviews), it should be noted that (as far as I could ascertain) Vollenhoven himself never employed the word 'reformational' or 'transformational' to characterise his own worldview or philosophy. These terms were used by some of his followers after his death. I guess the reason why Vollenhoven himself simply wrote about a Christian or a Scripturally obedient worldview or philosophy was that he did not intend - in a triumphalistic mode - to (re)transform the secular worldviews or philosophies of his time. Perhaps he was aware that such a mammoth mission was impossible, or not even the task of a Christian. Rather, his intention was to indicate synthetic tendencies amongst Christian thinkers themselves in order to be more obedient to God's revelation. This fact may serve as a warning to Vollenhoven's followers 
- including myself - to be careful about how they call their own worldview. It may liberate them of an impossible burden, viz. the idea that they will be in a position to transform the 'outside' world.

\section{Towards a new typology}

As personal retractationes (reconsidering my own previous position), I would therefore recommend dropping the usual typology of Christian worldviews as proposed by Niebuhr and his followers - also those in the Reformational tradition. This traditional categorisation of Christian worldviews into five different types includes some truth and may also be a handy pedagogical way to orientate students, but its methodological presuppositions make it suspect.

\section{New questions to be asked}

In the light of the preceding discussion the five different relationships between the Christian and the world or culture should be replaced by much more basic and more complex questions such as the following:

- Is this worldview (or philosophy) synthetic, trying to accommodate both God's revelation and unbiblical ideas?

- If so, what kind of method does it imply?

- Can this worldview or philosophy be described as secular anti-synthetic (or post-Christian), deliberately excluding the light of God's revelation?

- Or is this Christian worldview an honest attempt to be faithful to God's revelation (in other words antisynthetically Christian)?

- What does the structural or descriptive side of a particular worldview (the type of worldview in Vollenhoven's terms) look like?

- What is its basic normative direction (i.e. current in Vollenhoven's terminology)?

Many concrete examples of worldviewish and philosophical positions that Vollenhoven characterises in a more refined way than the usual categorisation can be found in Vollenhoven (2000, 2005a).

\section{No final Christian worldview}

The answer to the fourth question above does not imply that - at last - one has identified a perfect, final ex cathedra Christian worldview or philosophia perennis. It will still be fallible and incomplete. And because all of us are children of our own times, it will not be purified of every bit of synthesis. However, one should clearly distinguish between a kind of spontaneous or unintentional synthesis and a deliberate, conscious practice of synthesis-thinking.

\section{Concluding remarks}

Analysing and categorising worldviews - including Christian worldviews - seems to be a much more complex and difficult task than many popular books, with only four or five 'boxes', suggest. It even seems to me that the uniqueness of a 'Reformational' worldview, as well as other Christian worldviews, has not been identified fully yet. If so, this fact invites further thorough reflection. Such reflection should, of course, also include being critical of Vollenhoven's alternative as described above.

\section{Possible limitations of Vollenhoven's radical Christian worldview}

The following brief remarks may be made about possible limitations of Vollenhoven's own worldview. In some cases I will give my own brief response, whilst others will be left to the reader's reaction:

- Vollenhoven still worked from a Eurocentric-Western perspective, wrote for a Western audience and confined himself to the history of Western worldviews or philosophies. Klapwijk (1995) later emphasised the need for contextualisation in other cultural surroundings. Mouw and Griffioen (1993:16-19) distinguished, like Vollenhoven, between directional pluralism (a variety of religious directions) and associational pluralism (a diversity of social structures). But, different from Vollenhoven, they also added (like Klapwijk) contextual or cultural pluralism. (All three pluralisms could be descriptive as well as normative.) These three kinds of pluralities should be distinguished, but are closely related and influence each other reciprocally.

- Some (postmodern) Christians may also regard Vollenhoven's worldview and philosophy as too intellectualistic or rational, its main aim being to understand the world. To our irrationalist age this may be true. But Vollenhoven (1933:311) did not regard the emotional as something dangerous. Because of the close relationship between all human modalities, intellectual work includes an emotional aspect. There is also no religion without emotion. (Emotion without religion, however, does exist: many feelings are not directed at God.) I do not think Vollenhoven would have minded that I have indicated (cf. Van der Walt 2008:6-7) that any religion and worldview can participate in or reflect all fourteen modalities distinguished by Vollenhoven himself. It is thus not to be viewed simply as a logical and/or emotional construct or system.

- Not enough attention is given to the suffering of the world. Walsh (1992) writes: ' ... any worldview, if it is to be both biblical and illuminative of what human life is really like, must be a worldview that comprehends our brokenness and suffering'. (p. 10)

- Vollenhoven clearly distinguished between good and bad directions, but did he pay enough attention to the evil surrounding us? Is his worldview not perhaps too optimistic? (cf. Ramaker 2007, as per my argument above.)

- Vollenhoven still lived and worked in a more or less Christian environment. How can his worldview help us to live in our increasingly multireligious and secular societies? (A possible answer will be given below.)

- Vollenhoven did not write much about human sexuality or gender and about different theories in this regard, such as sexual polarity, sexual unity and sexual complementarity (cf. the excellent works by Allen [1985, 2002]). In his 
time, these were not yet such burning issues as today. Vollenhoven did criticise both anthropological dualism (according to which both men and women contain something transcendent or divine) and andrological dualisms (according to which only men participate in the divine) and, in this way, rejected the inferior position of women.

- From the side of Postmodernism, one may expect criticism such as the following: a (Christian) worldview is or may deteriorate into a totalitarian intellectual system, it usually has a claim to universal validity, or it simply promotes the power of the own group.

- From the Christian side, I have heard the following: a Christian worldview may silence the Scriptures, damping its inspiration and dynamics; it may try to replace a personal Relationship with God; or, with many Christians a gap exists between their worldview and real way of life.

- From a recent book by Bonzo and Stevens (2009), I pick up the following comments on a Reformational worldview: it must be more hospitable, it is used as a yardstick for orthodoxy and it has the tendency to pigeonhole others. Rather than providing rational justification, it should encourage genuine spirituality; more emphasis should fall on its pre-scientific character than on worldview as a theoretical system.

- Vollenhoven's philosophy is only another effort at schematism or to put worldviews and philosophies into different 'boxes'. He has gone around 'arresting' people, 'labelling' them and 'shoving' them into previously prepared cells. The imprisoning mesh is woven of type and trend and the person arrested will be charged guilty until he had proven the opposite! This, however, is rather true of many other textbooks about worldview and philosophy (cf. e.g. Dooyeweerd's [1959, 1979] four religious ground motives; Ferry 2007; Tarnas 2000) that have only a few labels at their disposal. Vollenhoven's much more nuanced approach allows several thousand possibilities to distinguish worldviews and philosophies. If his approach has to be called a prison, then it is a rather liberal one!

Some of these suggestions and accusations, however, deserve further attention, but that will have to wait for another article.

\section{A few implications of a radical Christian worldview for education}

Keeping in mind the central theme of the Koers-75 Conference, something has to be said about worldview and education. However, so much has already been written on this issue that I confine myself to a few general statements:

- Every human being is a religious being, with a specific worldview which influences every aspect of his or her life - education included.

- Education, therefore, cannot be something neutral (cf. e.g. Bonzo \& Stevens 2009; Clouser 1991; Garber 1996; Walsh \& Middleton 1984:163-174). It is either directed in obedience to God's revelation and will or not.
- We have a calling from God to walk with him in love. He appointed each one of us to an office. Our task is to create structures ruled by his diversified love command (troth in marriage, care in the family, justice in politics, etc.) The culture we create is the result of our responses to his diversified but foundational law of love. Part of this cultural activity is education.

- The Vollenhovian distinction and relationship between structure and direction should also be applied to society and education (cf. McCarthy et al. 1981). Structural plurality advocates different societal relationships with each its own, unique task and authority. A school is not the same as a church. And the state should not rule over schools, colleges and universities. Confessional plurality teaches that religious and worldviewish convictions should be allowed to give direction to the different societal structures. The ideal is that Christian, Muslims, Secularists, et cetera, should have the right to establish and govern their own schools and institutions of higher education, political parties, labour unions and so on.

- A Reformational approach therefore rejects the idea of public, secular schooling and institutions for higher education as the only option. It also rejects the basic distinction between 'private' (where religion and worldview may play a role) versus 'public' (where religion and worldview - except the secularist type - is excluded).

- Finally, in light of the above, let me try to give a simple definition of what I think Christian education should be. (I have tried to include into it some ideas of De Graaff [1966:112, 120] and Van Dyk [1990:156-161].) For me, education is a multidimensional, formative and worldviewishly determined activity, which gives normative direction to a person's development by guiding, unfolding and enabling her or him to understand and accept her or his place and calling in God's world.

\section{Conclusion: A time for action Christians should work together on a worldviewish level}

I do hope that this article does not give the impression that I am using a worldview approach as a yardstick to judge Christians as orthodox or heterodox. (For too long all kinds of confessional and dogmatic differences already divided Christians.) What I actually have in mind and hope for is that Christians, in spite of their many ecclesiastical differences, will in the future be willing to take hands and on the much broader perspective of a radical Christian worldview, based solidly on God's revelation, tackle the many burning issues of contemporary life, education being one of them. Only with an own Christian worldview will we be able to challenge the dominant worldview of secularism.

\section{There is still time to act}

Not only from a principal Reformational perspective (cf. my argument above), but also constitutionally, we as Christians in South Africa (still) have the right to let the voice of a real Christian worldview be heard - especially in education. 
The brief glimpses on the worldview of the eagle amongst Christian philosophers have again inspired us about our important place, calling and task in God's all-encompassing kingdom. May this African fish eagle's worldview in the future also fly through the African continent - after all, it also belongs to Africa.

\section{A clarion call}

Vollenhoven has assisted us to obey the Word of God to test the spirits (1 Jn 4:1) - even of differing Christian worldviews. Let us start flying higher, looking sharper, wider and deeper and let the world clearly hear our distinctive Christian voice. The silenced 'voice of Potchefstroom' (since about 2000) need to be revived. May Koers continue to light a small candle of hope in a rapidly secularising South Africa. Similarly, the voice from Amsterdam should be amplified to reach countries far away, outside the Netherlands. Or, in the terminology of our contemporary technological world: may a radical Christian worldview and its philosophical correlate in the future be empowered to fly like a satellite around the globe!

\section{Acknowledgements Competing interests}

The author declares that he has no financial or personal relationships which may have inappropriately influenced him in writing this article.

\section{References}

Allen, P., 1985, The concept of woman: The Aristotelian revolution, 750 BC - AD 1250 Eerdmans, Grand Rapids.

Allen, P., 2002, The concept of woman: Early humanist reformation, 1250-1500, vol. 2, Eerdmans, Grand Rapids.

Bavinck, H., 1888, De katholiciteit van Christendom en kerk, Zalsman, Kampen.

Bavinck, H., 1904a, Christelijke wetenschap, Kok, Kampen.

Bavinck, H., 1904b, Christelijke wereldbeschouwing, Kok, Kampen.

Bavinck, H., 1908, Wijsbegeerte der openbaring, Kok, Kampen.

Bartholomew, C.G. \& Goheen, M.W., 2010, The true story of the whole world: Finding your place in the biblical drama, Faith Alive Christian Resources, Grand Rapids.

Bediako, K., 1992, Theology and identity: The impact of culture upon Christian thought in the second century and in modern Africa, Regnum Books, Oxford.

Bonzo, J.M. \& Stevens, M. (eds.), 2009, After worldview: Christian higher education in a postmodern world, Dordt College Press, Sioux Center.

Carter, C.A., 2006, Rethinking 'Christ and culture': A post-Christendom perspective, Brazos Press, Grand Rapids.

Clouser, R.A., 1991, The myth of religious neutrality: An essay on the hidden role of religious beliefs in theories, University of Notre Dame Press, Notre Dame.

Colson, C. \& Pearcey, N., 1999, How now shall we live?, Tyndale House, Wheaton.

De Graaff, A.H., 1966, The educational ministry of the church: A perspective, Judels \& Brinkman, Delft.

Dooyeweerd, H., 1959, Vernieuwing en bezinning: Om het reformatorisch grondmotief Van den Brink, Zutphen.

Dooyeweerd, H., 1979, Roots of Western culture: Pagan, secular and Christian options, Wedge Pub. Foundation, Toronto.

Ferry, L., 2007, Beginnen met filosofie: Met andere ogen kijken naar je leven, Arbeiderspers, Amsterdam.

Garber, S., 1996, The fabric of faithfulness: Weaving together belief and behaviour during the university years, InterVarsity, Downers Grove.

Goudzwaard, B., 1984, Idols of our time, Dordt College Press, Sioux Center.

Goudzwaard, B., Vander Vennen, M. \& Van Heermst, D., 2007, Hope in troubled times: A new vision for confronting global crises, Baker Academic, Grand Rapids.

Griffioen, S., 2012, 'On worldviews', Philosophia Reformata 77(1), 19-56.
Heideman, E.P., 1959, The relation of revelation and reason in E. Brunner and $H$. Bavinck, Van Gorcum \& Co., Assen.

Hiebert, P.G., 2008, Transforming worldviews: An anthropological understanding of how people change. Baker Academic, Grand Rapids.

Klapwijk, J., 1970, Tussen historisme en relativisme, Van Gorcum \& Co., Assen.

Klapwijk, J., 1987, Kijken naar kopstukken, Buijten \& Schipperheijn, Amsterdam.

Klapwijk, J., 1995, Transformationele filosofie: Cultuurpolitieke ideën en de kracht van een inspiratie, Kok Agora, Kampen.

Kok, J.H., 1992, Vollenhoven: His early development, Dordt College Press, Sioux Center.

Kok, J.H., 1998, Patterns of the Western mind: A Reformed Christian perspective, Dordt College Press, Sioux Center.

Mccarthy, R., Oppewal, D., Petersen, W. \& Spykman, G.J., 1981, Society, state \& schools: A case for structural and confessional pluralism, Eerdmans, Grand Rapids.

Mouw, R.J. \& Griffioen, S., 1993, Pluralisms and horizons: An essay in Christian public philosophy, Eerdmans, Grand Rapids.

Naugle, D.K., 2002, Worldview: The history of a concept, Eerdmans, Grand Rapids.

Niebuhr, H.R., 1951, Christ and culture, Harper \& Row, New York.

Olthuis, J.H., 1970, 'Must the church become secular?', in J.A. Olthuis, H. Hart, G.C. Seerveld \& J.H. Olthuis (eds.), Out of concern for the church, pp. 105-125, Wedge Pub. Foundation, Toronto.

Ramaker, T., 2007, 'Scherpzinnig als een slang... de houding van Christenen in de hedendaagse cultuur', in J. Van der Stoep, R. Kuiper \& T. Ramaker (eds.), Alles wat je hart begeert; christelijke oriëntatie in een op beleving gerichte cultuur, pp. 145-163, Buijten \& Schipperheijn, Amsterdam.

Runner, H.E., 1982, The relation of the Bible to learning, Paideia Press, Jordan Station.

Schuurman, E., 1995, Perspectives on technology and culture, Dordt College Press, Sioux Center.

Smit, M.C., 1987, De eerste en tweede geschiedenis, J. Klapwijk (ed.), Buijten \& Schipperheijn, Amsterdam.

Spykman, G.J., 1992, Reformational theology: A new paradigm for doing dogmatics, Eerdmans, Grand Rapids.

Stellingwerff, J., 1992, D.H.Th. Vollenhoven: Reformator der wijsbegeerte, Ten Have, Baarn.

Stoker, H.G., 1967, 'Lewens- en wêreldbesckouing en lewenswandel \& Calvinistiese lewens- en wêreldbeskouing', in H.G. Stoker (ed.), Oorsprong en rigting, pp. 13-41, 42-82, Tafelberg, Cape Town.

Stoker, H.G., 1969, Beginsels en metodes in die wetenskap, Pro Rege Press, Potchefstroom

Stoker, H.G., 1970, Oorsprong en rigting, part 2, Tafelberg, Cape Town.

Taljaard, J.A.L., 1976, Polished lenses, Pro Rege Press, Potchefstroom.

Tarnas, R., 2000, The passion of the Western mind; understanding the ideas that have shaped our world, Pimlico, London.

Tol, A., 2010, Philosophy in the making: D.H.Th. Vollenhoven and the emergence of Reformed Philosophy, Dordt College Press, Sioux Center.

Tol, A., 2011, 'Reformational philosophy in the making', Philosophia Reformato 76(Dec), 187-215.

Van Der Walt, B.J., 2001, 'Why the salt has lost its quality: The influence of dualistic worldviews on Christianity', in B.J. van der Walt (ed.), Transformed by the renewing of your mind, pp. 1-42, Institute for Contemporary Christianity in Africa, Potchefstroom.

Van Der Walt, B.J., 2008, The eye is the lamp of the body: Worldviews and their impact Institute for Contemporary Christianity in Africa, Potchefstroom.

Van Der Walt, B.J., 2010a, 'An overview of the global presence of Christian Reformational philosophy and scholarship', in B.J. van der Walt (ed.), At home in God's world, pp. 127-151, Institute for Contemporary Christianity in Africa, Potchefstroom.

Van Der Walt, B.J., 2010b, 'A new paradigm for doing Christian Philosophy', in B.J. van der Walt (ed.), At home in God's world, pp. 152-182, Institute for Contemporary Christianity in Africa, Potchefstroom.

Van Der Walt, B.J., 2011, 'An Evangelical voice from Africa', In die Skriflig 45(4), 919-956.

Van Dyk, J., 1990, 'The practice of teaching Christianity', in S. Fowler, H.W. Van Brummelen \& J. Van Dyk (eds.), Christian schooling: Education for freedom, pp. 155-168, Institute for Reformational Studies, Potchefstroom.

Veenhof, J., 1968, Revelatie en inspiratie: De openbarings- en Schriftbeschouwing van Herman Bavinck in vergelijking met die der ethische theologie, Buijten \& Schipperheijn, Amsterdam.

Veenhof, J., 1980, 'Honderd jaar theologie aan de Vrije Universteit', in M. van Os \& W.J. Wieringa (eds.), Wetenschap en rekenschap 1880-1980: Een eeuw van wetenschapsbeoefening en wetenschapsbeschouwing aan de Vrije Universiteit, pp. 44-104, Kok, Kampen.

Veenhof, J., 1994, 'The relationship between nature and grace according to $\mathrm{H}$. Bavinck', Study Pamphlet 322(October), Institute for Reformational Studies, Potchefstroom.

Vollenhoven, D.H.Th., 1918, Die Wijsbegeerte der Wiskunde van teïstisch standpunt, Wed. G. van Soest, Amsterdam. 
Vollenhoven, D.H.Th., 1933, Het Calvinisme en de reformatie der wijsbegeerte, H.J. Paris, Amsterdam.

Vollenhoven, D.H.Th., 1992, Vollenhoven als wijsgeer: Inleidingen en teksten, A. Tol \& K.A. Bril (eds.), Buijten \& Schipperheijn, Amsterdam.

Vollenhoven, D.H.Th., 2000, Schematische Kaarten: Filosofische concepties in problemhistorische verband, K.A. Bril \& P.J. Boonstra (eds.), De Zaak Haes, Amstelveen.

Vollenhoven, D.H.Th., 2005a, The problem-historical method and the History of Philosophy, K.A. Bril (ed.), De Zaak Haes, Amstelveen.

Vollenhoven, D.H.Th., 2005b, De probleemhistorische methode en de Geschiedenis van de Wijsbegeerte, K.A. Bril (ed.), De Zaak Haes, Amstelveen.

Vollenhoven, D.H.Th., 2005c, Wijsgerig Woordenboek, K.A. Bril (ed.), De Zaak Haes, Amstelveen.

Vollenhoven, D.H.Th, 2005d, Isagôgè philosophiae: Introduction to philosophy, bilingual Dutch-English edn., J.H. Kok \& A. Tol (eds.), Dordt College Press, Sioux Center.

Vollenhoven, D.H.Th., 2010, Isagôgè philosophiae, 1930-1945, Text-critical edn., ed. A. Tol (ed.), Vrije Universiteit Uitgeverij, Amsterdam.

Vollenhoven, D.H.Th., 2011, Gastcolleges Wijsbegeerte: Erfenis voor het heden, K.A. Bril \& R.A. Nijhoff (eds.), De Zaak Haes, Amstelveen.
Vollenhoven, D.H.Th., n.d.(a), Inleiding in die Wysbegeerte, Isagôgè Philosophiae, transl. and processed J.A.L. Taljaard, PU vir CHO (Klasdiktaat), Potchefstroom.

Vollenhoven, D.H.Th., n.d.(b), Kort oorsig oor die geskiedenis van die Wysbegeerte, transl. and processed J.A.L. Taljaard, PU vir CHO (Klasdiktaat), Potchefstroom.

Walsh, B.J. \& Middleton, J.R., 1984, The transforming vision: Shaping a Christian worldview, InterVarsity Press, Downers Grove.

Walsh, B.J., 1992, Subversive Christianity: Imaging God in a dangerous time, Regius Press, Bristol.

Wentsel, B., 1970, Natuur en genade: Een introductie in en een confrontatie met de jongste ontwikkelingen in de Rooms-Katolieke theologie inzake dit thema, Kok, Kampen.

Wolters, A.M., 1989, 'On the idea of worldview and its relation to philosophy', in P. Marshall, S. Griffioen \& R.J. Mouw (eds.), Stained glass: Worldviews and social science, pp. 14-25, University Press of America, Lanham.

Wolters, A.M., 1990, 'Christianity and the Classics: A typology of attitudes', in W. Helleman (ed.), Christianity and the Classics, pp. 189-203, University Press of America, Lanham.

Wolters, A.M., 2005, Creation regained: Biblical basics for a Reformational worldview, Eerdmans, Grand Rapids.

Zuidema, S.U., 1971, Communication and confrontation, Kok, Kampen. 